\title{
Political Culture, Democracy and the Economic Crisis in Korea
}

\author{
JONGRYN MO \\ Gututute School of International Sudies, Yansei liniversity
}

The curent eionomic crisis reflects the failure of the political system as much as the einnomic system. It is the job of the former to correct the problems of the latter. But the Korean political system failed to carry out long overdue reforms and contain the unfolding financial crisis. The purpose of this paper is to invesrigate the direction of political reform in Kiorat in wize' of the fuilures of the political system to addiress the economic problems before the crisis. Among the many political prothems confirmting Kortat, I have highlighted the role of political culture. Emphasis on culuure does not mean that institutional reforms are unimportant. By all rieans, Korea should continue institutional reforms. But institutional reforms by themselves are insufficient to bring about the desired change in government performance. There is now a significant gap beraech cultural value and practices, and the formal nates of political institations. Unless this gatp is retuted, Korea will continut to suffer from political gridlock and stalemate, which u'as one of the leading causes for the economic crisis.

\footnotetext{
* Originally presented at the International Conlertence hosed by the lnstitute for Incernatiunal Trade and Cooperacion. Eula 1 Womans Unjersin on May 29, 1948.

the auther would like wo chank Kisilk (ho, Youngkwan Yoon and the edions of the ISR fore their helpful commenes on dn earlici draft. The author also benefited from the rescitch assistance of Kyung Yoon and Finkyng Sers.

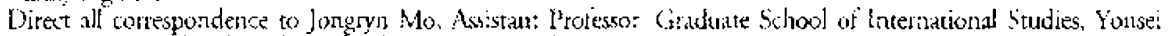
Cniversity. 134 Shinchon-dong. Scodaemun gu, Scous, 120749 , Kores.
} 


\section{INTRODUCTION}

Dolitical reform is urgent simply because the current political system is not working for I Korea. Since the Korean government barcly averted an economic collapse with the help of the International Monetary Fund and the rescheduling of commercial debrs with creditor banks. the government has been frustratingly slow to impletnent financial, labor and corporate restructuring programs necessary to get Korea back on its feer economically. Concerns about the pace of economic reform in Korea are mounting abroad. Increasingly, foreign observers point to the political system as the roor cause of the problem. Business W'eek, for example, warns that "old-style politics could sink the New Korea."

It is rather unfortunate that it is only recently that Korea's economic ifls have been atrributed to its political system. Even a castial observation of Korcan economic history in the last ten years shows that Korea 's economic peril has decidedly political roots. In fact, I argue in another paper (Mo and Moon, 1998), that the immaturity of Korean democracy has been one of che important causes (certainly, the one most "underrated" by analysts) of the current economic crisis. The argument in that paper is summarized below.

The Korean economic crisis was caused by both external and internal factors. Externally, Korea suffered from the contagious effecrs of the Asian financial crisis, and earlier from a global recession in its key export industries like semiconductors. The magnitude of the recession was so severe that Korea's terms of trade reached in 1996, the lowest point since the early 1980 s.

Although external shocks were significant, we cannot deny the fact that the Korean econony might have survived them, had its fundamentals been sound. The Korean economy had suffered from three inter-related structural constraints: underdeveloped financial markets, mounting foreign debts, and erosion of international compctitiveness of Korean firms. The question is then whether the government could have removed or alleviated these structural constraints with appropriate policies. My answer is, yes, the government could have done better.

Granted, it is all too casy after the face ro blame the government or politicians for policy failures. Powerful teconomic forces, domestic as well as international, interacted ro create a crisis environment. In light of their strength, it is fair to say that it would have becn difficult to prevent a crisis solely with government actions. But the Korean government cannot escape responsibility for the currenr crisis because it had for a long time, recognized, but failed to solve, the economic problems that caused the crisis; -- i.e., financial, chaebol, and labor reforms had been high on the national economic agenda but not implemented properly. We call discern common patterns in various reform efforts. lisist, no fundamental reforms were achicved. The government had nade progress in some areas, especially tabor reform in 1997, but even, some key issues, including the laws regilating layofts, were left unresolved. Under international pressure, the government undertook several financial liberalization and deregulation measures, but the Korean financial 
matket remained insulated and restricted when compared to international standards. Chavbol reforms wete probably the least effective. Instead of using market principles, the government turned to command-and-control type of regulations to contain the expansion of the dhateot - e eg. foreed dispersion of owsership and specialization of business lines.

Second, government policies have been inconsistent and incoherent. In almost every area of reform, the government has oscillated berween implementing reform policies and maintaining the status quo. Fluctuation of reform efforts has followed administrative and clectoral ycles. New gowernments began with antritious reform projects, but ended up back pedalling by the end of their adnsinistration. A typical example was the labor policy. Both Presidents Roh Tae Woo and Kim Young Sam espoused or tolerated reformist labor policies in the beginning, but soon reverted to pro-business positions. Policy toward the chatbol has exhibited a more complicated pattern. The governments of Roh Tae Woo and Kim Young Sam have excred conrinuous pressure on the dhaboh experimenting with various measures designed to moderate theit market power and enhance their competitiveness. Buc the intensity of their reform efforts has not been uniform; it tended to rise afier an election, but receded as another alection approached.

Third, the reform process has been top-down. Major reform acts by Kim Young Sam, such as the real name financial transaction system, were prodaimed unilacerally with executive order without much deliberation and debate. Many attribute this pattern to Kim Young Sarn's personal style. But the top-down approach reflects more troubling aspects of political process under demolvacy: That is, top-down reformus may have been the only alternative when groups with stakeholders conkd not negotiate an agreconent on their own. Since democratization began in 1987 , the grovernenenl experimented wich various mechanisms to foster dialoguc and cooperation between lahor and management; but labor and managemenc could not come to an agreemene on theil own. We see the same pattern with chickol reforms. Even after ten years of debate, the government is still searching for a vable thebol policy. Financial marter reforms have us been much different; the commuissions set up to facilicate compromise and agromeot did not produce lasting reforms. A typical example is the rivalsy berwecs the Ministry of Finance and Economy and the Bank of Korca ower primacy in monetary and barking policy. This conflict first came to the fore in 1989, and flared up even in the middle of the economic crisis in November 1997.

The picrure that we have depicted thus far of Korean political process is one of paralysis and gridlock. 'lthis is particularly truc if the interests of powcrful groups are threatened. In their effort to maximize their private interests, they play a ganne of attrition against their opponents instead of trying to find a negotiated setilement. "This faifure of dispute tesolution has been the most salient feature of the Korean democratic experience and explains why Korea bas falled to reform its economic system.

Covernment paralysis and gridlock also played an important role in the government handling of the comomic crisis. As discussed above, policy makers made several mustakes. Some of the mistakes were a matter of judgment and not a symptom of gridlexk. For example. the decision to defend the Korean won thesughout 1097 had its own justifica. 
tions and could not be dismissed based only on ex post evidence. The Kia debacle, however, was a typical case of gridlock. Kia (irs unions and management), creditor banks, and the government were powerful actors and the stakes were high for all. In pursuit of narrow self-intcrest, they entrenched themsclves in their positions and failed to make concessions.

During the critical month of November in 1997, the government was paralyzed for rwo weeks by bureancraric infighting over control of monerary policy and the supervision of financial institutions. The main antagonists were the Ministry of Finance and Economy and the Bank of Korea. Whar was remarkable about the whole episode was that the dispute had gone on for almost ten years and had come back to haunt the government at a time of crisis.

To summarize, the current crisis reflects the failute of the political system as much as the economic system. It is the job of the former to correct the problems of the larter. But the Korean political system tailed to carry out long overdue teforms and contain the unfolding financial crisis. The purpose of this paper is to investigare the direction of political reform in Korea in view of the failures of the political system to address the economic problems before the crisis. 1 will do this by reviewing and crivicizing the current discourses on pulitical reform in the next section. Afterwords, I will cxamine Korea's policical regime, institutions and culture as possible targets of political reform. I will pay particular atrention to political culcure and surgest an agenda for culturc shift.

\section{CURRENT DEBATES ON POLITICAL REFORM}

As far as we can remember, political reform has always heen a pressing issue in Korea. Before 1987, the overriding goal of political reformers had been democracy. Once democrarization began. however, the reformist agenda lost coherence and direction. Political reform debate since then has been driven nor by national interest and broad consensus but by narrow self-interest or partisan views of national interest, giving rise to divergent, offen conflicting views of political reform.

The most persistent and influential groups in the political rcform debatc have been former pro-democracy groups, consisting mainly of students, clergy, and dissidents. When democratization finally began in 1987, prodemocracy groups were excluded from the formal negotiations.s over the tetms of transition and the subsequent reorganization of the political system. To pro-democracy groups, the events in 1987 established a procedural democracy which they considered as only a first step toward the atrainment of "true" democracy. The substantive democracy that they envisioned was onc in which the interests of socially-disadvanraged groups like workers and the poor have properly represented in poticy outcomes as well as polirical processes.

Opposirion political parties have approached the problem of political reform from the perspective of their political interests. It is hardly an exaggeration to argue that former opposition political leaders like Kin Young Sam and Kim Dae-jung never considered political reform complete until they themselves won powcr. Kim Young Sam proclaimed 
his government to be the first civilian government, implying that his was the first "truly" democratic government. Kim Dae-jung was not much slifferent when he emphasized that he was the first opposition candidate who won the presidential election as if the transfer of power between two political partics represented the true test of democracy. Given these tendencies ro use political reform debate to pronotc private or narrow interesti, it is hard not to be skeptical about the mocivation of Kim Jong $\mathrm{P}^{\mathrm{i} i \mathrm{i}}$ in promoting a parliamentary system as a solution for Korea's political probicms.

More tecently, the term "political reform" has become a synonym for campaign finance reform. By any measure. the costs of campaigns and cketions are enormous in Korea. Fstimares of total campaign expenditures during the 1992 presidential election adone ranged from is $\$ 1.2$ in 3 billion. By cumparison, the total amoun of money spent in all the U.S. elections held in 1996 including presidential, congressional, and local elections was abnut US $\$ 3$ billion. Nevertheless, one wonders why recent debate on political setorm has been framed exclusively in terns of the financial cosss of elections, and not by other standards. I Jigh costs of campaigns are symproms, not causes, of the political problems. This fixation on monctary expenditures diverts our attention from other, more important defects of Korean democracy. In a country of Korea's sire, US $\$ 1$ or 2 billion is not a large sum of money, ar least not large enough to bring about an coonomic crisis. It is not a coincidence that campaigns to weaken the role of noney politics have been led by the chotebol who find it increasingly costly to sustain the level of political and campaign concributions desired by politicians. As providers of campaign funds, the chacbol are particularly sensitive to the amount of money that they have to coneribute to politicians.

As we can see so tar, the dehate on political reform has nor been based on careful analysis of the relationship benween policical reform and government perfornance, and in particular, economic performance. The chatebol and media like to shatacterize the current political system as "high cost, low efficiency" (Mo, 1997). But they are silent about how and why the political system profuces inefficient outcomes. We need a teform program with strong theoretical and enapirical foundarions. We should not repeat the mistakes of bureacratic reform; is is hard to think of any pressing problems or needs that can justify: frequent bureaucratic reorganizations made in the name of government reform. One ironic "benefir" of the economic crisis has been to expose the structural weaknesses of the Korcan political syssem. as well as its economy, for everyone tor sce. Since it has already been said that the failures of the Korean political system had contributed to the connomic crisis, we procet to the next question: Why did the Korean policical system fail?

\section{CAUSES OF POLITICAL BREAKDOWN: LEADERSHIP, RFGIME, INSTITUTIONS, OR CULTURE?}

The success of a political system depends on its ability to produce good policies. But dhe production or supply of good policies is enes automatic because they typically face strong opposition from these who are positioncd to lese from them. An efficient political 
system means by definition that such obstades are overcome reasonably well. If a political system is not run efficiently, that is, good governance is not attained, we can think of four possible reasons for it, leadership, regime type, institutions, and political culture. 'lhese factors are not mutually cxclusive and may interact together even though their relative significance may differ.

If we adopt the view that institutional and cultural variables intermediate interest group comperition, we can see that the mere presence of vested interests against reforms does not explain reform failures. Although many Koreans blame the unwillingness of the government and the business elite for clinging onto their private interest and privileges which caused the defeat of most eform initiatives, such resistance is, in a sense, expccted. Therefore, instead of blaming the vested interests, we should ask why they could not be overcome.

\section{Leadership}

The most popular answer seems to be leadership or lack thercof. Many attribute govmment failures such as politial gridlock, bureaucratic politics, and incffectual monitoring to incompetenr executive leadership (Moon and Kin, forthoomings). Despite democratic institutional constraints, the president in South Korea is expected to play an important role in formulating, monitoring, and implementing public policies. It is mone so because of the historical legacy of an imperial presidency, in which power is heavily concentrated in the hands of the president and his staff. Presidents Roh lat Woo and Kim Young Sam were not kuown to have strong political and cconomic convictions and thus became indexisive when faced with difficult policy choics. In particudar, President Kin Young Sam has been widely criricized for his lack of expertise, knowledge, and compctence, especially on economic issues. Thus, he delegated his power and authority to his staff, but failed to monitor the formulation and implementation of economic policies. As past history illustrates, lack of executive leadership, commitment and monitoring has always ended in ficree bureaucratic fighting and policy gridlock. In view of this, Kim's dismal leadership performance can be seen as a critical catalyst, which aggravared government failutes.

Although President Kim Young Sam's leadership may have contributed to the worsening of economic conditions in Korea, blaming it all on him represents wishful thinking on the part of those who believe in the leadership theory. Democracy and the ruke of law are emphasized precisely because government performance cannot be decided by or does not depend on the personal characteristics of leaders. A counny may get luchy with one benevolent authoriarian leadet, but history shows that such benevolent rule does not last. I.eadership is often a convenient excuse for not taking the time and effort to cxamine. other determinants of government pertormance. Leadership is also an analyrical black hole, since it is almost impossible to define, and predict the conditions under which it can be successfully exercised. For these reasons, we have no choice but to look beyond the lcadcrship issue to find causes for government failures. Recent developments confirm this skepricism toward the leadership theory. Presidert Kim Dae Jung, whom no one accuses 
for lacking of leadership, has been unable to carry out the necessary reforms even under the conditions of national connomic emergency.

\section{Regime Type}

Since Korea's economic troubles began to surface in the late 1980 s, e.g., rising labor costs and inflation, it is tempting to link the two developments -i. e., democratization and the economic crisis. Indeed, democratization has brought various structural changes wo the Korcan conomy such as the ascendance of labor unions, expansion of social welfare programs, the activation of distributive politics, and the erosion of government control of the economy (Mo and Moon, 1998). We have also scen fundamentul changes in the relationships among state, capital and labor, and their relative influence on the policymaking process. Given the magnitude of the economic and political changes that Korea has cxperienced under democracy, it is narural to ask how the current economic crisis is refated to it.

Unfortunatsly, it is impossible to investigate the ffects of reginc change on macroeconomic performance, especially, the economic crisis of 1997 , because we do not know what might have happened in the absence of the regime change, that is, if the pre- 1987 auchoricarian regine had remained in powet. We can only speculate on what might have happened under alternative tegimes, e.g., an authoriturian regine or a mature and consolidatal democracy. Elsewhere, l took the position that had Koratn democracy been consolidated er matured sooner, it would not have produced such disastrous policy outcomes (Mo and Moon, 1998). That is, I refect the view that the process of democratic transition and consolidation is inherently less favorable to economic pertionance. The problem was not democracy itseif, but how it was practiced in Korea.

In general, the relationship berween regime type and economic performance is tenuous at best. Many theoretical arguments have been advanced as to why one regine is superior wo the another in promoting conomic growah. "Demo-Prosperity" theories argue that denocracy unhances or is at least compatible with cconomic growth, since it better pro-. eces property rights and decentralizes power, while the "Demo-Disaster" school points to negarive effects of democracy such as distributive demands. But there is no a priori reason why regime $y^{\text {pe }}$ per se would have significan effects on economic performance. Auroctacy an, in theory, curc many ills of domocracy such as excessive distributive politics, policy imconsistency and biases for consumption, but there is no guarantee that autocrats would no thanage clecit conomy for personal gains (Preeworksi and limongi, 1993). Emprivical evidence is also mixed; many studics ofo not fund statistically significant effects of regime type on economic growth.

Since gond governance secms posible under either democracy or aurhoritarianism, we should took for a set of institutions conducive to good governance under a given regime. This does not mein that I consider this delate on tegime type as a foregone conclusion. Democracy is not at value that we should protect at all cost. litst of all, there is no universally acepted definition of demociacy, so it is beter to leave all options open. 'To most Koreans in 1987, democracy meant only the direct election of the president. Scoond, if 
we find that democracy compromises other national objectives such as long-tern economic development, we should be willing to adjust in the pace of democratization.

\section{Institutions}

Having shown that leadership and regime type do not explain reform fuilures, we are left with the other two possible sources of failure, institutional defects and Korean poilical culture. Let's consider institutional problems first. In 1987, Korea chose a presidencial system because pro-democracy groups and opposition parties favored it over a parliamentary system that the authoritatian tegime had originally suggested. They wanted a presidential system for two teasons. First, a presidential system with the direct election of the president had become a symbol of democracy, and represented a cleaner break with the authoritarian regime compared to a parliamencary system. Second, they wanted a strong and decisive national execurive.

Ihe most common problems associated with presidentialism are divided government and the "lame duck" phenomcnon. During the first three years of his presidency, Presidenc Rak 'Tae Woo suffered from a divided government because his party failed to win a majority in the National Assembly in 1998. But the divided government did not last long. In 1990, Roh engineered a three-party merger involving his party and two opposition parties to secure a dominant position in the National Assembly. However, from 1990 to 1997, Korean presidents held a solid majority in the National Assembly. Theretore, it is difficult to atribute government failures to the problem of divided government under a presidential system.

Lame duck effects are more plausible, since President Kim Young Sam was not in a strong position to manage the deteriorating conomic conditions in 1997, which was the last year of his presidency. The structural problems of the Korean economy, howvever, had been recognized even when President Kim erzjoyed approval ratings of over 90 percent in the beginning of his administration. 'Therefore, 1 conclude that the lame duck problem was of marginal significance in accounting for government performance.

In general, it is difficult to link any political institurions to government failunes, especially, in the contexs of the econonic crisis. Some have suggested that electoral reforms such as a combination of proportional representation, and large electoral districts, are solutions to reducing the costs of elections, but I cannot think of any direct link between electoral systems and the failures of retorm efforts.

Again, this does not mean that reform of political institurions should be rejected. Even though existing political institutions may not have been a significant factor in accounting for the current conomic crisis, they can still be improved and reformed if that enhances Korea's long-term economic performance. As a starring point for the debate on institutional reform, let's consider Cox and McCubbins (1996), who studied the effects of political institutions on government performance. They explain why there are variations in the degree, to which the state can act decisively and it is responsive to the broad public as opposed to narrow special intercsts. Their main argument is that the electoral and consti. tutional rules of the state shape political actors' incentives and capabilities in such a way as 
to determine the degrees of state decisiveness and responsiveness.

Consider the decisiveness of a political system. According to Cox and Mccubbins (1996), the decisiveness of the state depends on how many branches in the government have veto pouter in the legislative process, and how many parties exist to control those veto gates. Ir is the constitution that divides powers among the diffetent branches of levels of the government, while it is the electoral system that shapes the fragmentation of the party system. State indecisiveness results if and only if the separation of powers co-exists with the scparation of purpose, that is, when there are many veto gates in the political sy'stem and many political parties competing to conerol them. "They atso argue that the privatizarion of public policy (e.g., rent-seeking and pork) is most likely when there is both a constiturional separation of power and an electoral sepasarion of purpose. Although Cox and McCubins (1996) do not apply their theory to the problem of economic growth, it has clear implications for the effects of political institutions on economic growth. Clearly, those political institutions promocing statc decisiveness and responsiveness are conducive to ecomomic growth.

The implications of $C o x$ and McCubbins (1996) for Korea are clear. Guven the fragmentation of the party system (no political party is likely to win an outright majority in any foreseeable fucure), the Korean political system is vulnecable to gridlock and rentseeking it it has multiple veto gares. 1'herefore, Korea should consider reducing the number of vero points in the systen, such as adopting a parlianentary system with a strong prime minister. The problem is, of course, that Korea has a tradition of presidentialisn, and a majority of Korean cicicets favor it ove parliancntarism. If Korea maintains irs presidential system, it can still experinent with institutional reforms such as a run-off in the presidential election, simultaneous holding of presidential and National Assembly elections, and wider use of proportional representation (Diamond, 1998). The objectives of these reforts measures should be to make the government more decisive and responsive to broad national interest. What kinds of impact institutional reforns will have on the perfomance of Korean democracy depends on the excene to which instizutional deferts are undermining the proper workings of democracy. Nevertheless, I rertain skeptical about the effects of insritutional teforms, which are not accompanied by changes in political culcure.

\section{Political Citiure}

In light of the persistent failure of Korean demoxacy to reform under different institutional artangements, one naturally looks to political culture for possible answers. Indeed. many scholars have questioned the viability of liberal democracy in a country like Korea, where Confucian attitudes toward power dominate political values and practices (l'ye, 1985; Huntington, 1991). Recent empirical scudies on Korean political culture confirm the persistence of atuthoritarian values among the elite as well as the public. Based on surwy data, Han and fuh (1981) find that only 30 percent of Korean citizens as have both modern social values, and democratic values and attiudes (display of trust and tolerance towatd others and belief in equality and rights). Shin (1998) finds that only 9 percent of 
Korean voters ate what he calls representative democrats, i.e., those who endorse democratic institutions and reject authoritarian solutions. Almost half of the respondents 49 percent) support democratic institutions, but refuse to reject authoritarian solutions fully. Others are strong or weak supporters of authoritarianism. While Koreans support democracy-in-principle, their support for democracy-in-action is lukewarm at best.

This ambivalent attitude toward democracy has broughe a mismatch of domain between democratic outfit and authoritarian ethos. Democratic transition has not onjy altered political landscape by expanding space for pluralistic maneuvets by social forces, but also has fostered democratic reforms and institutional changes. However, major political actors including excutive leadership, bureauctacy, the ruling National Congress for New Politics (NC.NI'), and even peak polinical organizations have not completely shed their authoritarian behavior and have been unable to settle their disputes without authoritarian "guidance." Authoritarian inertia, deeply embedded in the people and institutions, has persisted, undermining the very process of democratic consulidation, nule of law, and tespect for negotiated outcomes. lailure to artain finc-tuning between democratic outit and authoritarian ethos has deepened political and policy gridlock without producing any meaningful compromises.

\section{POLITICAL CULTURE AND DEVELOPMEN'T}

I have argued that characreriscics of Korcan political culture such as authoritarianism,

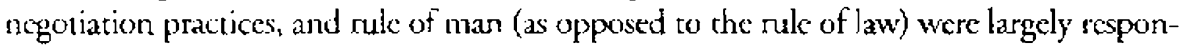
sible for the government railures contributing to the onset of the economic crisis. Thus, the solutions to Korea's political problems must involve some shif in culture. Exactly how we should approach the problem of cultural shift is unclear. Some try to find answers in Confuciat philosophy itself, arguing that it can, if practiced correcty, present an alternative, such as a more advanced forn of denocracy than individualistic Westem democracy (Hahm and Ryu, 199)8). Others seem to believe that further democratization along the lines of social democracy will help establish democratic culture in civic society $($ Im, 1997). Before thinking about solutions, it seems that we should first understand the relationship between culute on the one hand, and instirutions and political and economic development on the other.

\footnotetext{
: Cututa! thensy of democracy was jopular in the 1960 s hecause the only developing countrias with a working

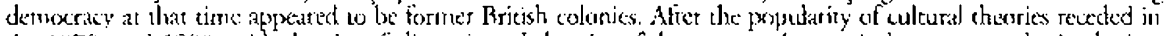

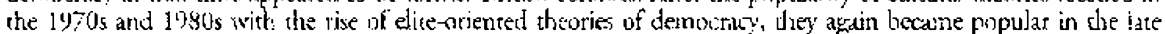

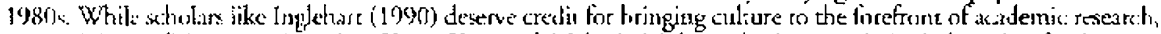
it was Asian politiciass sucti as Lee Kwan Yew and Mahacir. Mohanad who popularized the role of culture in

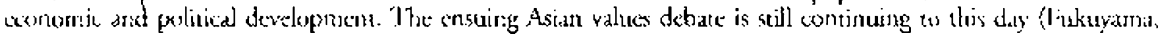

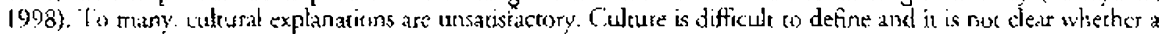

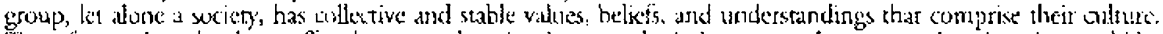

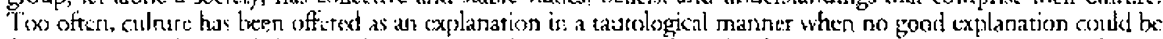

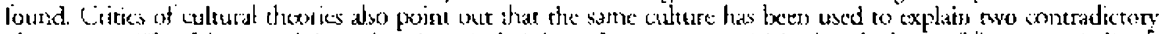
phemonena. The debure on Asjan values is rypical Asian values ase now criticized as the hasis of "crony capicalism" even thisugh they were praised as promoting stable. long-term coonomic relations anomg economic actors ir the

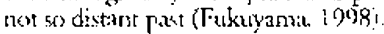


Mainstream studies about political culture have examined the link between cultural characteristics and the devclopment of democracy with a focus on the notion of democrathe values and atcitudes (Diamond. 1993). It has been argued that the development and maintenance of democracy needs, or at least would be enhanced by, the presence of some cultural orientations such as moderation, coopetation, hargaining, and accommodation among political elites. "These elements of political culture are needed to cope with one of the central dilemmas of democrag: to balance cleavage and conflict with the need for consensus" (1)ramond, 1993 ). From this point of view, what is needed is culcural re-orientitione, which pronote democtacy and as a resule, contribute we enhanced economic performance.

But it seems that there are more than one way in which political culture can affect nacional economic performance. To find out these other links, we must underscand how political culturc affects actual government policies. Fconomists and grame theorists offer their perspectives on the role of culture. To succeed, a sociery musc resolve ubiquitous collective action problems caused by the existence of uncertainty and transaction costs. When there is too much uncertainty, formal institutions are not compreteresive or flexible enongh to solve collective action problems. To cope with a high level of uncertainty or unforesen contingencies, a socicry or organization has to cotne up with a loose set of norms and beliets, called culture (Kreps, 1990 ). According to this perspective, the role of culture is instrumental and functional; it is designed to promote efficient transactions. $A$ related. but slightly different idea is viewing culture as focal points, natural reterence points around which across' expectations converge. When there are mote than onc mutually heneficial agrement and actors cannot decide which one to choose, they have to coordinare with each othes. When explicit cootdination is unfeasible or prohibitively expensive, it helps to have focal points, toward which actors will gravitate without explicit communication. According to this perspective, the role of culture in promoring efficient transactrons is limited to guiding the actors' expectations; culture does not change the incentive structure of relationships. Seen this way, political culture contributes to the thoice of beter pululic policies by helping political actors resolve their collective action problems.

What really matters to national performance, however, may be not culnural tharacteristics $p e \%$ se but the degree of cultural consensus. A nation may be successful when its culture is cohverent and adaptable, enabling it to define and attain its goals, and when there is the leas discance bewecn the presailing culture and the formal rules and regulacions of its instituejons." When a country has conflicting cultural values with one set dominating actual practices and the other shaping the fomal nites and regularions,--i.c., its culture is incoherent and inconsistent-it fails to pertorm successfully.

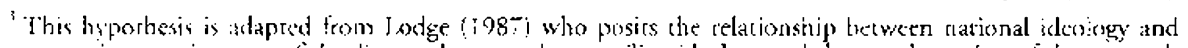

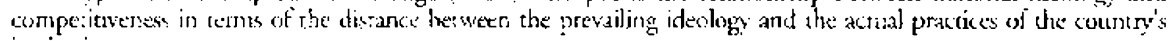
instifutions.
} 
fable 1. Cliture and national Plergormanice

\begin{tabular}{|c|c|c|}
\hline & Before & Now \\
\hline culture & 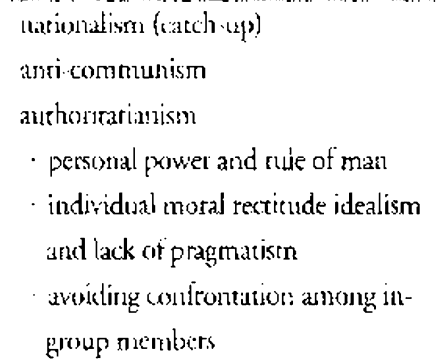 & $\begin{array}{l}\text { antionalism } \\
\text { authoritarianism } \\
\text { - new values } \\
\text { democracy } \\
\text { frec markets }\end{array}$ \\
\hline iestrintionls & 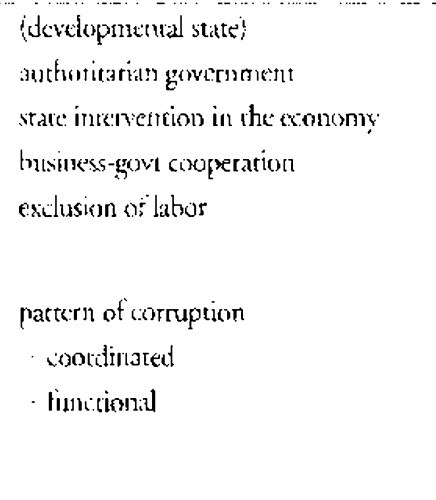 & 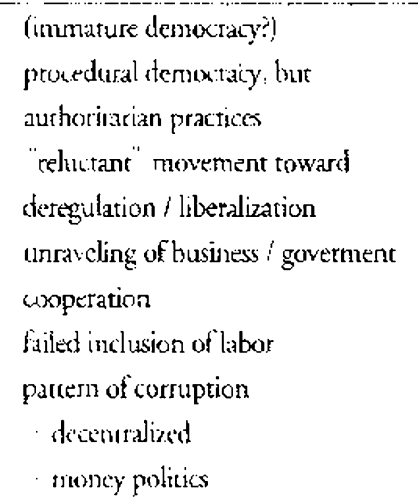 \\
\hline clideacrizations & $\begin{array}{l}\text { celturas conscrisus } \\
\text { compatibility berween cilfure } \\
\text { and instirutions. }\end{array}$ & $\begin{array}{l}\text { crisis of values } \\
\text { incompatibility herween culture } \\
\text { and insriturions } \\
\text { fold values dominate the actual } \\
\text { practices, but new values have } \\
\text { shaped dhe institutions! }\end{array}$ \\
\hline retorm agenda & & 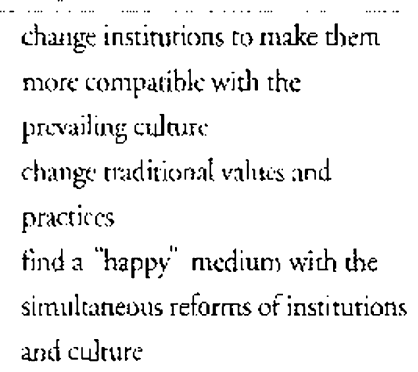 \\
\hline
\end{tabular}


If we apply this hypothesis to Korca, we can see why Korea has suffered from government paralysis and econonic troubles (lable 1). The term, "the developmental," state is ofen usect to describe the instituional arrangements of the Korean political conomy during years of rapid conomic growth. We often overlook the fact that Kotean traditional political values were comparible with four main features of the developmental state, i.e., authoritarian regime, state intervention in the economy, business-government cooperation, and exclusion of labor. In the 1980) and 1990s, however, new values like democracy and free markets have become much more influential. Necdless to say, these new values were not comparible with the features of the developmenral state. Thus, the gap between prevailing idenlogies and the formal rules and regulations of institutions began to wider. Old values and culture have dominated the actual practices, whilc new values have been embodied in the formal rules and regulations of institutions. According to my hypothesis, a large gap berween culture and institutions may have undernined economic performance.

Where these is incompatibility in culture and institurions, there can only be three solutions. Korea should change its formal institutions to malie then more compatible with prevailing culture: change the prevailing culture itself; or find some "happy" medium with simultaneous retorms of both institutions and culture. If Korea wants to follow the Western model of liberal democracy and free-market economy. it has no choice but to shed its traditional political culture. Many seem to yearn for a new Korean model of economic and political development, he it a Confucian democracy or a Scandinavian social democracy: Whichever firlal destination Korea is heading toward, it must undergo a slow and difficult process of culturad tran formation.

\section{AN AGENDA FOR CULTURAL SHIFI}

Cultural analysis does not have to be normative or open-ended. Modern ganne theory has shown that culurad probiems cant be systematically studied. Its basic message is that like all other political phenomena, culture can be a result of individual intercses and incentives. If so, ir can be changed and shaped with appropriate incentives. If we fail to cxplain the emergence and evolution of culture, understanding culture has only intellectual value, and not practical and prescriptive value.

A country's culture, in a waly, represents the body of knowledge and understanding that it has accuntulated over a long cime, so it is unlikcly to change casily. Thus, it may take a crisis to change the culture in any meaningful way. One lime of research that scholars may pay atention with regard to the cvolution of national culure is based on gametheoretic models of emetgence of cooperative norms (Axelrod. 1984). Decisions to cooperate aue latgely a function of political actors' individual incentives, i.e., the cost and benefit of cooperation. Bur when a large number of people are insolved, collecive monitoring and enforement of a conerariwe agreement becomes cructial, and the prevailing noms and culture within the group are ou inportant determinant for successfully overcoming the coltective atrion problems. Norms and culture themselves are products of individual 
choice, and research shows the role of "deviants" in the emergence of cooperative norms. If there is a critical mass of reformers or deviants, cooperative norms can emerge endogenously.

\section{Table 2. AN Ageida yor Cultural ReForm}

\begin{tabular}{|c|c|c|}
\hline & Illeg & Legal, but tradicional pracuices \\
\hline enforcement / implementation & 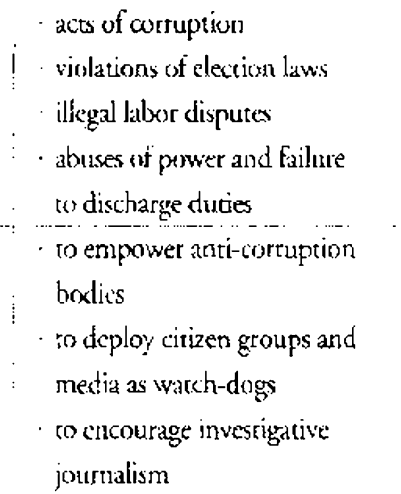 & $\begin{array}{l}\text { lick of behayiural requisites } \\
\text { for democsacy (tolcrance, } \\
\text { moderation, a willingness to } \\
\text { compromise, and pragmarism) }\end{array}$ \\
\hline $\begin{array}{l}\text { legalization or accommodation } \\
\text { of traditional practicesso }\end{array}$ & 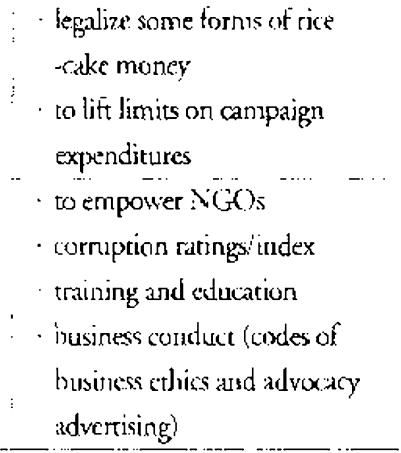 & $\begin{array}{l}\text { (o) empower } \mathrm{NGOS} \\
\text { comuption ratingsindex } \\
\text { training and education } \\
\text { business conduct juddes of business } \\
\text { (thics aud advocacy advertising) }\end{array}$ \\
\hline $\begin{array}{l}\text { improve quality of reform } \\
\text { debate }\end{array}$ & $\begin{array}{l}\text { research } \\
\text { tissemination of tesearch } \\
\text { tindings and intormation } \\
\text { public fonıms } \\
\text { media warch } \\
\text { co discourage yellow journalisn } \\
\text { and denaands for finding } \\
\text { scapegnats }\end{array}$ & $\begin{array}{l}\text { research } \\
\text { dissemination of research } \\
\text { findings and intormation } \\
\text { public tonums } \\
\text { media watch } \\
\text { - } 5 \text { discoutage yellow journalism } \\
\text { and demands for finding } \\
\text { scapegoats }\end{array}$ \\
\hline national reconciliacion & $\begin{array}{l}\text { selective pardons fur past } \\
\text { irfractions } \\
\text { prasitive sanctions in addition co } \\
\text { negative actors }\end{array}$ & $\begin{array}{l}\text { acknowledge the past } \\
\text { concributions of traditional } \\
\text { practices } \\
\text { positive over negative } \\
\text { sanctions }\end{array}$ \\
\hline
\end{tabular}


Although much more research needs to be done, I offer some thoughts on measures that we should take to change political culture (see Table 2). I first distinguish two catcgeries of culural practices, oncs that are illegal under Korean law and orhers that are legal, but incompatible with democratic values. For the first category, enforcement of existing laws and regulations should be the focus of cultural reform, while the second category requires a more comprehensive and educational reform approach. The measures that 1 suggest for both categories are divided into four groups; legalizing and accommodating traditional practices; promoting agents of change; improving the quality of reform debate; and call for narional reconciliation.

1. To the extent that it does not undermine the democratic nature of our political system, we should make political institutions more comparible with political culture. Culnural change is incvitably slow, and we should adapt wo the transition by reducing transitional cost. One way to reduce the costs is to move from the other end, that is, changing features of the political system. We can start by changing some of the untealistic regulations on campaign financing

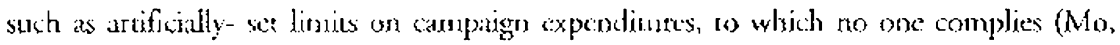
1.0977 .

2. We should encourage reformers to form critical masses. There are many organizations that can ace as agents of change such as churches and wiversities. They should stat educaring their memibers on the consequences of adhering to traditional practices and values - e.g., accepeng gifis and meats from political candidates.

3. Political reform sebate has been highty ernotional and devoid of serious, reasoned discourse. We tend to blane noral failures of individuals, and find scapogoats inscead of loxking or anderlying structural causes. Once we recognize that it is political culture, which lics at the rout of the problem, we can see why blaming others is counter productive. The rote of intellccuals and media is important in this process.

4. It is urgene that we develop a more balanced view of our past practices in order to build politinat suppor for reforen. As many have argued. the developmental state represened an "opumal" "expenses to the condivions that existed ar that time. "I has, we should recognize the conuribucions of ofd pazcrices, while trying to adapt them to changing circumstances.

\section{CONCLUSION}

I reviewed several key issues concerning the urgent problem of political reform in Korea. Among the many policical problems contronring Korea, I have highlighred the role of political culturs. Fmphasis on culture does not mean that instinutional reforms are. unimporrant. By all means, Korea should continue institutional reforms, But institutional reforms by themselves are insufficient wo bring about the desired change in government performance. There is now a significant gap berween cultural values and practices, and the formal rules of political instiutions. Unless this gap is reduced, Korea will continue to suffer from political gridlock and stalemare, which was one of the leating causes for the economic crisis. 


\section{REFERENCES}

Axetrod, Robert. 1984. The Evolution of Coopenations. New York: Basic Books.

Cox, Gary W., and Mathew D. MoCubbins. 1996. "Strucure and Policy: The Institutional Determinants of Policy Outcomci." Department of Political Science, University of California at Sas Uiego. Typescript.

Diamond, larry. 1993. "Introduction: Political Culure and Democracy." In Palitical Culture and Democmey in Dezeloping Countries, ed. Larry Diamond. Boulker, Colo.: Lynne Reinner Publisters.

-.--1 1998. "Whac Kind of Presidential Democracy for Korea?" Hoover nstitution. Typescript.

Fukuyama, Francis. 1998. "Asian Values, Korean Values, and Democratic Consolidation." Geonge Mascon University. Typescript.

Han, Bax Hor, and Sooyoung Euh. 1987. Hankuk Jungchi Munwha [Korean Political Culture]. Seoul, Korea: Bup Mur $S_{a}$.

Fahm, Chaibong, and Singyoung Rhyu. 1998. "Democratic Reform and Consulidation in Souch Korea: The Promise of Democricy." In Democratization and Globalization in Korea: Assessment and Prospects, eds. Chung-in Moon and Jongryn Mo. Seoul, Korea: Yonsei University J'ress.

Huntington, Samuel 13. 1991. The Third Wave: Democratization in the Late Tuentieth Century. Nurman, (Okla.: Ciniversity of (Oklahioma Press.

In, Hyug Baek. 1997. "Consolidation of Korean Democracy: Assessments and Prospects." In Democratization and Reform in South Küra, ed. Bae Ho Hahn. Seoul, Korea: The Sejong Institule.

Inglehan, Ronads1. 1990. Culture Shift in Aduanced lodustrial Countries. Princeton, N.I.: Princeton University Press.

Kreps, David. 1990. "Corporare Culture and Economic Theory." In Perspectives on Positive Politicul Eronomy, eds. James E. Alt and Kenneth A. Shepsle. Cambridge: Cambridge University ['ress.

Lodye, Creorge C. 1987. "Intmoduction: Ideology and Country Analysis." In Idenlogy and National Comperitiveness, ats. George C. Lodge and Ezra F. Vogel. Cambridge, Mass.: Harvard Business School Press.

Mo. Jongryn. 1997. "Hankukui Jungchi Gaehyuk" ["Policical Reform in Korea"]. In Shin Jwaghai Gat Syuk Kusaje [The Reform Agenda of the Netw Administration!. Seoul, Korea: Kotea Econonic Rescarch linstitute.

Mo, Josngty, and Chung-in Moon. 1998. "Denucracy and the Origins of the Korean Eomumic Crisis." In Dennociay and the Market, eds. Clung in Moon and Jongryn . Wo. Stanford: Hoover Instirution Press.

Moon, Chung-in, and Song-min Kim. Forthcoming, "Democracy and Economic Performance in Souts Korea." In Democratic Iransition and Consolidation in Korea, eds. Lamy Lhamond and Buzungkrook Kim. Baltimore, Md.: Johns Heppkins P'ress.

Pye, Lucian W. 1985. Asian Pouer and Politis: The Cultural Dimencions of Authority. Cambridge, Mass: Harvard L'niversity l'ress.

Shin, Doh Chull 1998. "The Evolution of P'upulas Support for Democracy during the Kim Young Sam Crovernment." Paper presented at the Conference on Institutional Reform and Democratic Consolidation in Korea. Stanford, California, January 8-9. 